\title{
Environmental Swipe (ES) Streamline Protocol-ORNL Testing Fiscal Year 2016 Report
}

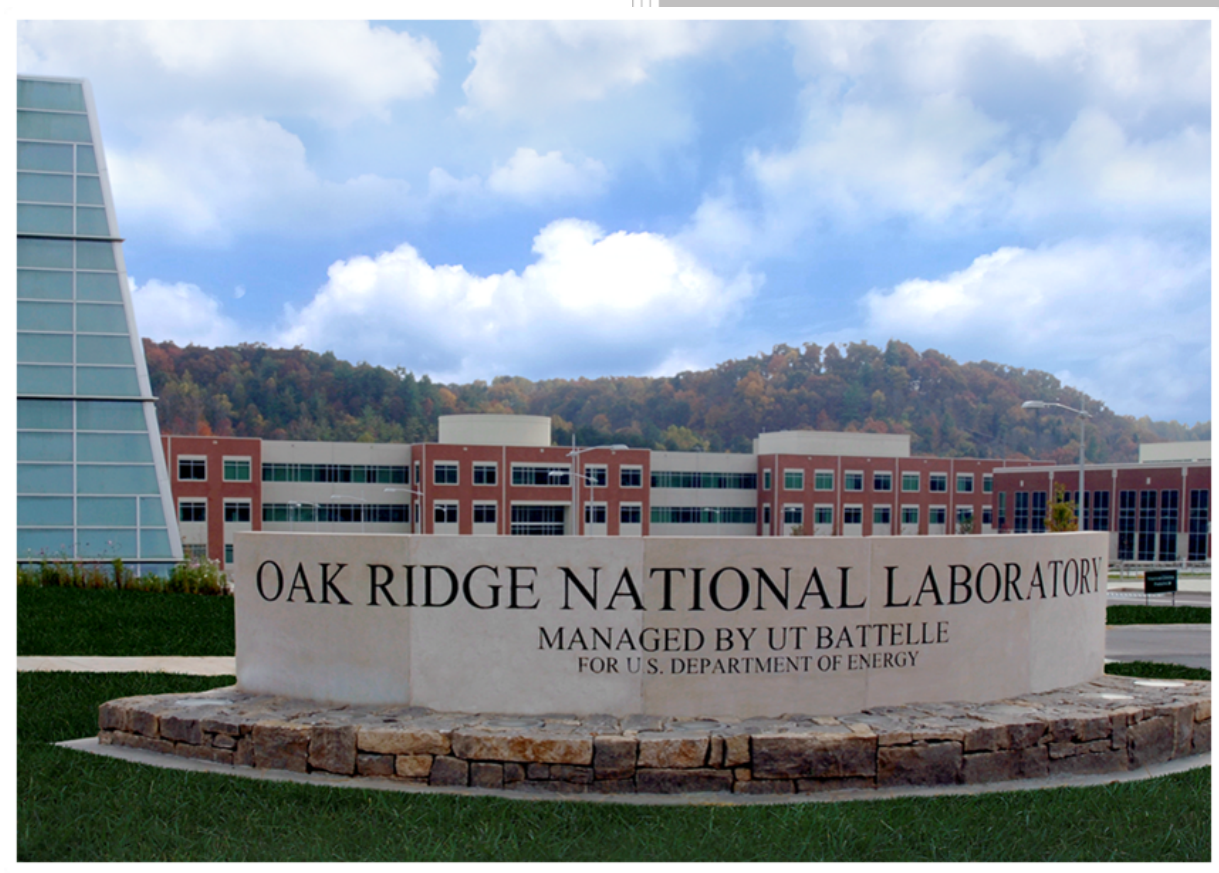

Debra Bostick

Cole Hexel

October 2016

Approved for public release. Distribution is unlimited. 


\section{DOCUMENT AVAILABILITY}

Reports produced after January 1, 1996, are generally available free via US Department of Energy (DOE) SciTech Connect.

Website http://www.osti.gov/scitech/

Reports produced before January 1, 1996, may be purchased by members of the public from the following source:

National Technical Information Service

5285 Port Royal Road

Springfield, VA 22161

Telephone 703-605-6000 (1-800-553-6847)

TDD 703-487-4639

Fax 703-605-6900

E-mail info@ntis.gov

Website http://www.ntis.gov/help/ordermethods.aspx

Reports are available to DOE employees, DOE contractors, Energy Technology Data Exchange representatives, and International Nuclear Information System representatives from the following source:

Office of Scientific and Technical Information

PO Box 62

Oak Ridge, TN 37831

Telephone 865-576-8401

Fax 865-576-5728

E-mail reports@osti.gov

Website http://www.osti.gov/contact.html

This report was prepared as an account of work sponsored by an agency of the United States Government. Neither the United States Government nor any agency thereof, nor any of their employees, makes any warranty, express or implied, or assumes any legal liability or responsibility for the accuracy, completeness, or usefulness of any information, apparatus, product, or process disclosed, or represents that its use would not infringe privately owned rights. Reference herein to any specific commercial product, process, or service by trade name, trademark, manufacturer, or otherwise, does not necessarily constitute or imply its endorsement, recommendation, or favoring by the United States Government or any agency thereof. The views and opinions of authors expressed herein do not necessarily state or reflect those of the United States Government or any agency thereof. 
Chemical Sciences Division

ENVIRONMENTAL SWIPE (ES) STREAMLINE PROTOCOL-ORNL TESTING FISCAL YEAR 2016 REPORT

Debra Bostick

Cole Hexel

Date Published: October 2016

Prepared by

OAK RIDGE NATIONAL LABORATORY

Oak Ridge, TN 37831-6283

managed by

UT-BATTELLE, LLC

for the

US DEPARTMENT OF ENERGY

under contract DE-AC05-00OR22725 



\section{CONTENTS}

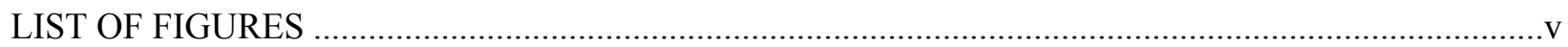

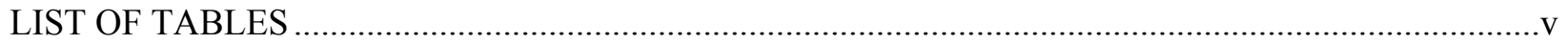

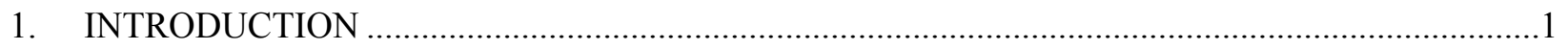

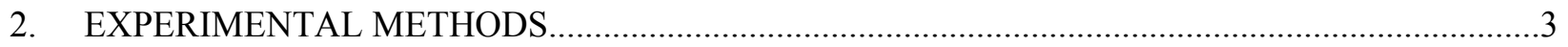

2.1 EXPERIMENT 1: DETERMINATION OF BLANK U LEVELS WITH $2 \mathrm{M}$ $\left(\mathrm{NH}_{4}\right)_{2} \mathrm{CO}_{3}-2 \mathrm{M} \mathrm{H}_{2} \mathrm{O}_{2}$ PROTOCOL USING TEXWIPE TX304 (LOT A080AK) COTTON SWIPES .

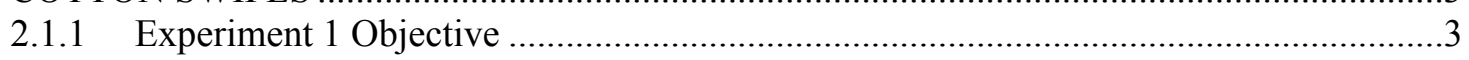

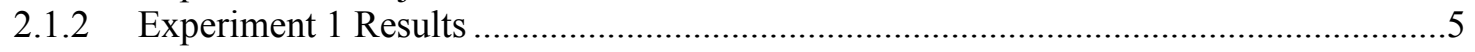

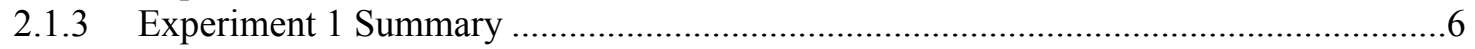

2.2 EXPERIMENT 2: DETERMINATION OF BLANK U LEVELS IN TEXWIPE TX304 (LOT A080AK) COTTON SWIPES AND THREE SYNTHETIC SWIPES USING $2 \mathrm{M}$

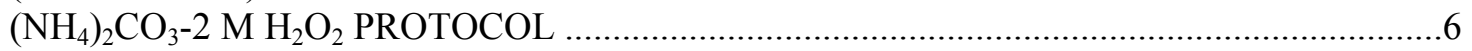

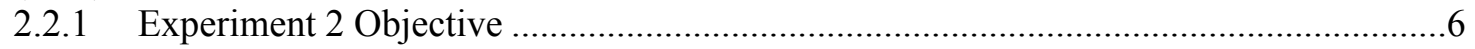

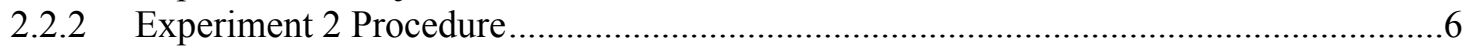

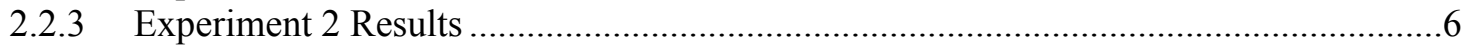

2.3 EXPERIMENT 3: REDUCING SALT CONTENT IN PNNL LEACHATE TO

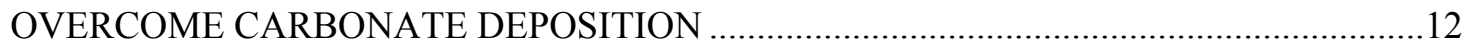

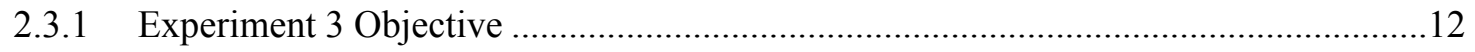

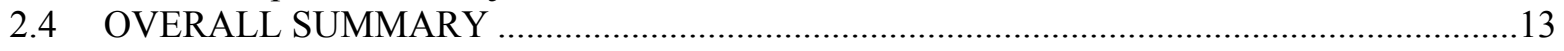

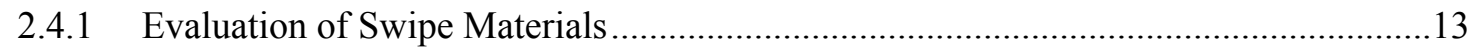

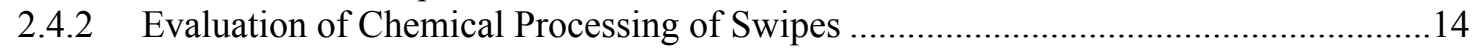

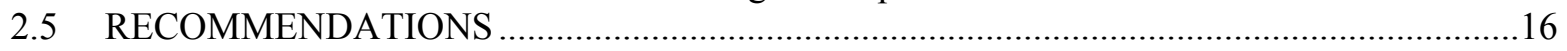

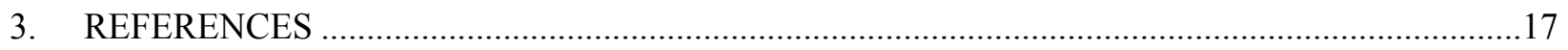





\section{LIST OF FIGURES}

Figure 1. Cotton (a), PTFE coated fiberglass (b), RCF tissue (c), and Zorflex ${ }^{\circledR}$ fabric (d),.......................2

Figure 2. $2 \mathrm{M}\left(\mathrm{NH}_{4}\right)_{2} \mathrm{CO}_{3}-2 \mathrm{M} \mathrm{H}_{2} \mathrm{O}_{2}$ leached samples chemical blank (a), cotton (b), fiberglass (c),

RCF tissue (d), and Zorflex ${ }^{\circledR}$ fabric (e).

Figure 3. Loose carbon fibers produced in handling of the Zorflex ${ }^{\circledR}$ FM 50K carbon fabric. ....................7

Figure 4. Carbon coating of MC-ICPMS cones using a $2 \mathrm{M}\left(\mathrm{NH}_{4}\right)_{2} \mathrm{CO}_{3}-2 \mathrm{M} \mathrm{H}_{2} \mathrm{O}_{2}$ sample matrix..............8

Figure 5. NWAL column separations vs. leach processing. ....................................................................

Figure 6. Ashed cotton (a), fiberglass (b), and RCF tissue (c). ...........................................................10

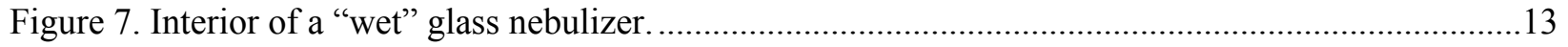

\section{LIST OF TABLES}

Table 1. ORNL 2015 reagent blanks using ORNL NWAL protocol............................................................

Table 2. TexWipe TX304 cotton swipe blanks (Lot no. A080AK) using ORNL NWAL protocol..............4

Table 3. ORNL analysis of reagent blanks and half TX 304 cotton swipes (Lot no. A080AK) using the PNNL leachate method

Table 4. U Isotopic and mass composition of 2 inch by 4 inch swipes treated with the $2 \mathrm{M}$ $\left(\mathrm{NH}_{4}\right)_{2} \mathrm{CO}_{3}-2 \mathrm{M} \mathrm{H}_{2} \mathrm{O}_{2}$ leachate method

Table 5. Isotopic composition of $\mathrm{U}$ in thermally decomposed $2 \mathrm{M}\left(\mathrm{NH}_{4}\right)_{2} \mathrm{CO}_{3}-2 \mathrm{M} \mathrm{H}_{2} \mathrm{O}_{2}$ leachate............9

Table 6. U Isotopic and mass composition of 4 inch by 4 inch swipes treated using ORNL NWAL procedure

Table 7. Comparison of reagent blanks generated by ORNL NWAL and Carbonate Leach methods

Table 8. Comparison of 4 inch by 4 inch swipe blanks generated by ORNL NWAL and Carbonate Leach methods 



\section{INTRODUCTION}

As a sub-section of the NA241 project entitled "Faster, Simpler, Lower-Cost Laboratory Analysis of Environmental Samples," Oak Ridge National Laboratory (ORNL) was to function as a Network Analytical Laboratory (NWAL) for validation, verification, and review of analytical methods developed under the auspices of this project. ORNL would also provide technical input on alternative analytical protocols for analyzing bulk environmental samples submitted for uranium (U) and/or plutonium $(\mathrm{Pu})$ determinations by the International Atomic Energy Agency (IAEA). The final ORNL task would then be to summarize findings as stated in this end-of year report.

The proposed streamlined method selected by Dr. Shane Addleman and coworkers at Pacific Northwest National Laboratories (PNNL) is based on the leaching of non-refractory U compounds using an ammonium carbonate-hydrogen peroxide extractant. This particular leachate has been used in the past to extract $U$ from ores and downstream purification cycles of ore leachates. ${ }^{1,2,3,4}$ The salient feature of this protocol is that it might be possible to provide an analytical method for $U$ in bulk environmental samples that would reduce sample processing times, increase throughput of existing NWAL laboratories to meet present and future analytical demands, and reduce analytical cost per sample. For these reasons, the carbonate leachate method might be of particular interest to the IAEA NWAL members.

The IAEA relies upon NWAL laboratory analysis of cotton swipe samples acquired during on-site inspections of safeguarded facilities to provide physical proof of treaty-compliance activities. Typical exposed swipes contain 10-1000 ng $\mathrm{U}$ and 0-10 pg Pu in the presence of metallic impurities such as $\mathrm{Pb}$, $\mathrm{W}, \mathrm{Hg}, \mathrm{Fe}$, and concomitant oils and greases. Actinide isotopic abundances are of primary importance to IAEA analysts in making the determination of international treaty compliance. Measurement quality goals are set at a $\leq 2 \%$ accuracy for ${ }^{235} \mathrm{U} /{ }^{238} \mathrm{U}$ at $>10 \mathrm{ng} \mathrm{U}$ and $20 \%$ accuracy for ${ }^{240} \mathrm{Pu} /{ }^{239} \mathrm{Pu}$ at $>1 \mathrm{pg}$ at a $95 \%$ confidence level. Current NWAL chemical processing requires separation of actinides from sample contaminants in order to provide a highly accurate isotopic analysis is extensive and time consuming. The demanding analytical protocols therefore can delay reporting of results to IAEA analysts by a couple of months. The goal of this project is to combine the rapid extraction of non-refractory U compounds from alternative swipe materials to provide a rapid, and perhaps higher, collection efficiency method with lower background $\mathrm{U}$ content. At the same time the new method would still need to be amenable to other forms of instrumental analyses, such as thermal ionization mass spectrometry.

The PNNL method is based on a carbonate leach of non-refractory U compounds from several possible alternative swipe materials. During FY2016, the method validation at ORNL included assessing U content in reagents, identifying possible perturbations of $U$ isotopic signatures by reagents and/or synthetic swipe materials, and determining the ease of implementing the PNNL leach protocol. PNNL staff provided the following description of the ammonium carbonate-hydrogen peroxide extraction procedure that ORNL is to evaluate:

1. Gently place an exposed swipe in a borosilicate glass or plastic vial.

1. D. A. White and K. Edwards, "Degradation of ammonium carbonate based uranium leach solutions by sulphide minerals and possible methods of control," Hydrology (1982): 27-34.

2. I. W. Croudace et al., "Investigation of an alleged nuclear incident at Greenham Common Airbase using TI-mass spectrometric measurements of uranium isotopes," Environ. Sci. Technol. 34 (2000): 4496-4503.

3. F. Clarens et al., "The oxidative dissolution of unirradiated $\mathrm{UO}_{2}$ by hydrogen peroxide as a function of $\mathrm{pH}$," $J$. Nucl. Mater. 345 (2005): 225-231.

4. S. C. Smith et al., "Kinetic study of uranium residue dissolution in ammonium carbonate media," J. Radioanal Nucl. Chem. 282 (2009): 617-621. 
2. Add freshly prepared $2 \mathrm{M}\left(\mathrm{NH}_{4}\right)_{2} \mathrm{CO}_{3}-2 \mathrm{M} \mathrm{H}_{2} \mathrm{O}_{2}$ in an amount sufficient to cover the swipe; cap vial.

3. Use a table shaker at $100 \mathrm{rpm}$ to vibrate the vial for 18 hours. Alternatively, the vial can be initially shaken and allowed to stand for 18 hours.

4. Remove the treated swipe.

5. Dilute an aliquot of the leachate with $2 \%(\mathrm{w} / \mathrm{w}) \mathrm{HNO}_{3}$ prior to analysis by ICPMS.

ORNL was to compare the standard NWAL protocol relative to the $2 \mathrm{M}\left(\mathrm{NH}_{4}\right)_{2} \mathrm{CO}_{3}-2 \mathrm{M} \mathrm{H}_{2} \mathrm{O}_{2}$ sample leaching to evaluate the chemical processing time, $\mathrm{U}$ background of processing reagents, and precision and accuracy of measured $U$ isotopic composition of prepared samples by multi-collector inductivelycoupled plasma mass spectrometry (MC-ICPMS). The ORNL NWAL protocol uses the following steps to completely destroy a cotton swipe, aggressively dissolve $\mathrm{U}$ and $\mathrm{Pu}$ particles, and isolate the actinides from concomitant contaminants such a $\mathrm{Pb}, \mathrm{Hg}, \mathrm{W}, \mathrm{Th}, \mathrm{Am}$, etc. The resulting processed sample provides highly purified $\mathrm{U}$ and $\mathrm{Pu}$ aliquots for subsequent analysis by MC-ICPMS. The NWAL chemical processing sequence is as follows:

1. Ash the swipe in a tube furnace to produce a light ash.

2. Dissolve the ash in $10 \mathrm{~mL} 4 \mathrm{M} \mathrm{HNO}_{3}-5 \mathrm{M} \mathrm{HF}$.

3. Dry down the solution and digest the residue with $4 \mathrm{M} \mathrm{HNO}_{3}-5 \% \mathrm{H}_{2} \mathrm{O}_{2}$.

4. Dissolve, heat, and then dry down the residue with $4 \mathrm{M} \mathrm{HNO}_{3}$ to remove trace HF. Repeat.

5. Bring up the residue in $4 \mathrm{M} \mathrm{HNO}_{3}$; spike a portion with ${ }^{233} \mathrm{U}$ and equilibrate to determine $\mathrm{U}$ mass.

6. Spike a $2^{\text {nd }}$ portion with ${ }^{244} \mathrm{Pu}$ to determine sample $\mathrm{U}$ and $\mathrm{Pu}$ isotopic composition and $\mathrm{Pu}$ mass.

7. Pass the isotopic fraction through a stacked Eichrom TEVA-UTEVA cartridge set.

8. Wash contaminants from the cartridges. Separate the cartridges.

9. Elute $\mathrm{U}$ from UTEVA and Pu from TEVA.

10. Submit each fraction for MC-ICPMS.

A secondary task of this project was to evaluate novel synthetic swipe materials relative to the cotton twill weave swipe (TexWipe TX304) typically used by IAEA for bulk environmental sampling. Synthetic swipe materials hold the promise of having a lower nascent $U$ background compared to cotton swipes. Additionally, certain swipe materials may be amenable to alternative mass spectrometric analysissecondary ionization mass spectrometry (SIMS) in particular. To this end, three synthetic swipe materials listed below were provided by PNNL for testing at ORNL.

1. PTFE-coated fiberglass fabric

2. RCF carbon semi-transparent tissue

3. Zorflex ${ }^{\circledR}$ FM $50 \mathrm{~K}$ carbon fiber fabric

Figure 1 shows the physical characteristics of the cotton twill fiber (a) relative to the synthetic swipes. Synthetic matrices include a woven fiberglass fabric coated with polytetrafluoroethylene (PTFE) (b); a refractory ceramic fiber (RCF) composed of an aluminum silicate wool that can be purchased in several densities (c); and Zorflex ${ }^{\circledR}$ FM 50K fabricated from activated carbon having a microporous structure to yield a highly adsorptive surface area $(\mathrm{d})$. 


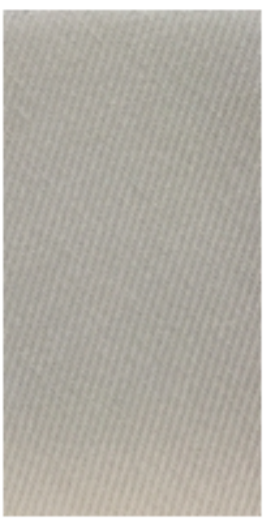

a) Rugged

twill weave

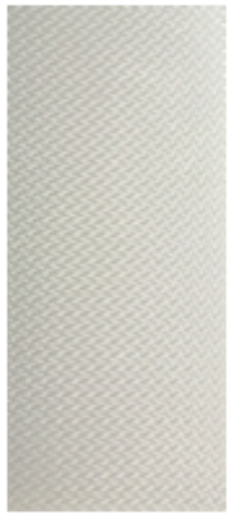

b) Smooth,

sturdy weave

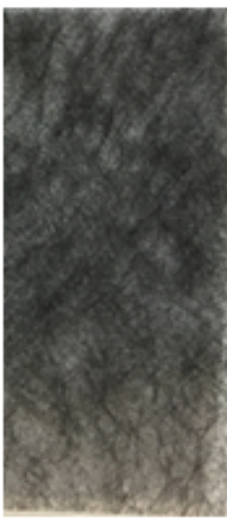
c) Thin semi- transparent tissue

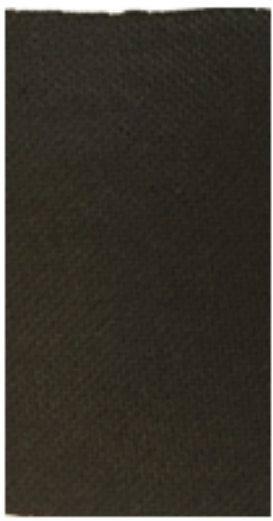

(d) Sturdy weave, sheds fibers

Figure 1. Cotton (a), PTFE coated fiberglass (b), RCF tissue (c), and Zorflex ${ }^{\circledR}$ fabric (d).

ORNL performed several experiments to define the suitability of the ammonium carbonate-hydrogen peroxide extraction procedure for NWAL analysis relative to the extraction procedure currently used by ORNL for actual IAEA samples. Because the carbonate leachate method is selective for $\mathrm{U}$ but not $\mathrm{Pu}$, ORNL testing was confined to reviewing $U$ measurement only. Experiment 1 was designed to compare the amount of $U$ found in reagent blanks (commonly referred to as process blanks) for both the ORNL NWAL and leachate protocols. Additionally, the amount of leachable U extracted from a highly characterized lot of TX304 cotton swipes (Lot A080AK) using the NWAL protocol would be compared with the amount of leachable $\mathrm{U}$ obtained by the milder chemical matrix of $2 \mathrm{M}(\mathrm{NH} 4)_{2} \mathrm{CO}_{3}-2 \mathrm{M} \mathrm{H}_{2} \mathrm{O}_{2}$. At issue would be the determination of whether the leachate method would prevent the collection of approximately $1.7 \mathrm{ng}$ of $\mathrm{U}$ inherently present in the cotton fibers as is encountered with the NWAL method. The goal of Experiment 2 was to make a side-by-side comparison of the NWAL and leachate protocols to measure the $U$ mass and isotopic composition of 16 sq. in. samples of cotton swipes relative to synthetic swipe materials (Teflon-coated fiberglass, RCF carbon tissue, and Zorflex ${ }^{\circledR}$ FM 50K conductively-coated carbon fiber). Experiment 3 determined the upper limit in concentration of (NH4) ${ }_{2} \mathrm{CO}_{3}-2 \mathrm{M} \mathrm{H}_{2} \mathrm{O}_{2}$ that could be introduced into a desolvating nebulizer used to introduce a sample into an MC-ICPMS.

\section{EXPERIMENTAL METHODS}

\subsection{EXPERIMENT 1: DETERMINATION OF BLANK U LEVELS WITH $2 \mathrm{M}\left(\mathrm{NH}_{4}\right)_{2} \mathrm{CO}_{3}-2 \mathrm{M}$ $\mathrm{H}_{2} \mathrm{O}_{2}$ PROTOCOL USING TEXWIPE TX304 (LOT A080AK) COTTON SWIPES}

\subsubsection{Experiment 1 Objective}

Blank U levels and isotopic composition for reagent and IAEA swipe blanks were compared between the full NWAL separation protocol used by ORNL and the carbonate method developed by PNNL. ORNL creates process blanks by including an empty tube in the ashing furnace along with tubes containing IAEA cotton swipe samples. Subsequent to furnace ashing all tubes are rinsed similarly and the acid collected is partitioned to prepare one aliquot to determine the $\mathrm{U}$ concentration and a second aliquot to determine the $\mathrm{U}$ isotopic composition. The $\mathrm{U}$ concentration aliquots are spiked with ${ }^{233} \mathrm{U}$ and analyzed without further purification. The isotopic aliquots are passed through stacked Eichrom UTEVA columns 
before analysis. All isotopic fractions are analyzed using a Thermo Scientific Neptune MC-HR-ICPMS. Alternatively, spiked fractions can be analyzed on a Thermo Scientific Element 2 single collector ICPMS.

Historical ORNL Column Reagent Blanks. ORNL prepared 9 reagent blanks while processing IAEA samples throughout 2015. All were processed in either a Class 100 or Class 1000 cleanroom. The average reagent blank contained $U$ with the isotopics and concentrations listed below in Table 1.

Table 1. ORNL 2015 reagent blanks using ORNL NWAL protocol

\begin{tabular}{cccccccccc}
\hline${ }^{233} \mathbf{U} /{ }^{238} \mathbf{U}$ & $\mathbf{2 \sigma}$ & ${ }^{234} \mathbf{U} /{ }^{238} \mathbf{U}$ & $\mathbf{2 \sigma}$ & ${ }^{235} \mathbf{U} /{ }^{238} \mathbf{U}$ & $\mathbf{2 \sigma}$ & ${ }^{236} \mathbf{U} /{ }^{238} \mathbf{U}$ & $\mathbf{2 \sigma}$ & $\mathbf{U}, \mathbf{n g}$ & $\mathbf{2 \sigma}, \mathbf{n g}$ \\
\hline $4 \mathrm{E}-06$ & $1.3 \mathrm{E}-05$ & $5.8 \mathrm{E}-05$ & $3.5 \mathrm{E}-05$ & $7.55 \mathrm{E}-03$ & $6.1 \mathrm{E}-04$ & $8 \mathrm{E}-07$ & $1.6 \mathrm{E}-05$ & $2.9 \mathrm{E}-02$ & $4.1 \mathrm{E}-02$ \\
\hline
\end{tabular}

Historical ORNL Swipe Blanks processed by NWAL Column Chemistry. Texwipe TX304 cotton swipes from manufacturing Lot no. A080AK were chosen to compare swipe blank content by the two different chemical processing methods. Lot no. A080AK swipes were provided and shipped to ORNL by Dr. Khris Olsen (PNNL), who is the primary provider of validated swipes materials for IAEA. This particular lot of Texwipe TX304 swipes is being used by three DOE NWAL laboratories to provide a consistent, low-U material to create swipe blanks and loaded swipes for the DOE NWAL internal QC program. Because swipes from this lot have been highly characterized for U concentration and isotopic composition a number of times by several DOE labs using their various IAEA protocols, consolidated consensus data can be used to compare known $\mathrm{U}$ content and isotopic composition with that acquired using the carbonate extraction protocol with standard column chemistry.

ORNL analyzed six 4 inch by 4 inch Texwipe TX304 swipes (Lot no. A080AK) throughout 2015 using full ORNL NWAL protocol. Data was acquired using a Thermo Scientific Neptune Plus MC-ICPMS. The swipe isotopic aliquot contained approximately $1 \mathrm{ng}$ of $U$ and the spiked aliquot contained approximately $0.3 \mathrm{ng}$ of $\mathrm{U}$. The average assay and isotopic content for six A080AK cotton swipes processed and analyzed by the ORNL NWAL protocol is listed below in Table 2.

Table 2. TexWipe TX304 cotton swipe blanks (Lot no. A080AK) using ORNL NWAL protocol

\begin{tabular}{cccccccccc}
\hline${ }^{233} \mathbf{U} /{ }^{238} \mathbf{U}$ & $\mathbf{2 \sigma}$ & $\mathbf{2 3 4} / \mathbf{2 3 8}$ & $\mathbf{2 \boldsymbol { \sigma }}$ & ${ }^{235} \mathbf{U} /{ }^{238} \mathbf{U}$ & $\mathbf{2 \boldsymbol { \sigma }}$ & ${ }^{236} \mathbf{U} /{ }^{238} \mathbf{U}$ & $\mathbf{2 \sigma}$ & $\mathbf{U}, \mathbf{n g}$ & $\mathbf{2 \sigma}, \mathbf{n g}$ \\
\hline $2.4 \mathrm{E}-07$ & $7.4 \mathrm{E}-07$ & $7.49 \mathrm{E}-05$ & $8.2-06$ & $7.39 \mathrm{E}-03$ & $1.7 \mathrm{E}-04$ & $9.2 \mathrm{E}-08$ & $1.0 \mathrm{E}-06$ & 1.65 & $2.1 \mathrm{E}-01$ \\
\hline
\end{tabular}

\subsubsection{Experiment 1 Procedure}

In the current study, ORNL testing was initiated by cutting two virgin TX304 swipes (Lot no. A080AK) in half within a laminar flow hood in a Class 100 lab so that cotton swipe area matched that of submitted synthetic swipe samples. Each of the four portions were multiply folded and placed in an individual 50 $\mathrm{mL}$ acid-leached Falcon centrifuge tube. Fresh $2 \mathrm{M}\left(\mathrm{NH}_{4}\right)_{2} \mathrm{CO}_{3}-2 \mathrm{M} \mathrm{H}_{2} \mathrm{O}_{2}$ was prepared from $99.999 \%$ Aldrich $\left(\mathrm{NH}_{4}\right)_{2} \mathrm{CO}_{3}$ and Ultrex $30 \% \mathrm{H}_{2} \mathrm{O}_{2}$. As depicted in Figure 2, the solution was immediately used to add $10 \mathrm{~mL}$ to the tubes sufficient to completely immerse the folded swipes, and $5 \mathrm{~mL}$ added to 3 additional Falcon tubes to prepare reagent blanks. Capped tubes were manually shaken to thoroughly wet the swipes before being placed in an ultrasonic bath for 30 minutes. The tubes then soaked for another 18 hours. Leached ICPMS cups were gravimetrically loaded with a $50 \mu \mathrm{L}$ IRMM57 spike, $0.75 \mathrm{~mL}$ resulting $2 \mathrm{M}\left(\mathrm{NH}_{4}\right)_{2} \mathrm{CO}_{3}-2 \mathrm{M} \mathrm{H}_{2} \mathrm{O}_{2}$ leachate, and $0.75 \mathrm{~mL}$ high purity $2 \%(\mathrm{w} / \mathrm{w}) \mathrm{HNO}_{3}$ using leached pipet tips. The final ${ }^{233} \mathrm{U}$ concentration in the vials was $1 \mathrm{ng} / \mathrm{g}$-solution. Samples were analyzed using a Thermo Scientific Element2 HR-ICPMS. Isotopic composition of the swipe $U$ in the aliquot was calculated by mathematically stripping out the presence of the IRMM57 spike counts before determining sample U isotopic ratios. 


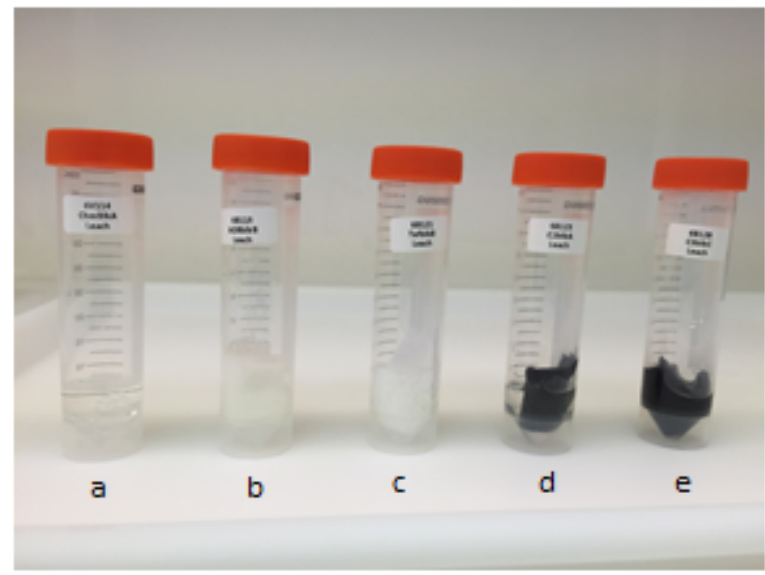

Figure 2. 2M $\left(\mathrm{NH}_{4}\right)_{2} \mathrm{CO}_{3}-2 \mathrm{M} \mathrm{H}_{2} \mathrm{O}_{2}$ leached samples chemical blank (a), cotton (b), fiberglass (c), RCF tissue (d), and Zorflex® fabric (e).

\subsubsection{Experiment 1 Results}

On average, a $10-\mathrm{mL}$ solution of $2 \mathrm{M}\left(\mathrm{NH}_{4}\right)_{2} \mathrm{CO}_{3}-2 \mathrm{M} \mathrm{H}_{2} \mathrm{O}_{2}$ (ChemBlkA-C) contained $0.0032 \pm 0.0028$ $(\mathrm{k}=2) \mathrm{ng}$ of $\mathrm{U}$ which is an insignificant amount relative to $\mathrm{U}$ present in the half-sized cotton swipes. The $2 \%(\mathrm{w} / \mathrm{w}) \mathrm{HNO}_{3}$ diluent for a given sample leachate also did not contribute significantly to the $\mathrm{U}$ assay of each swipe sample.

NWAL calculates the method detection limit using the critical limit parameter Lc. This value is defined as the concentration, at a proscribed probability, that an analyte is present at a rate above background. It is calculated based on the value of the student's t statistic $(t)$ for a given probability $(\alpha)$ and degrees of freedom (df) multiplied by the standard deviation of chemical blanks $\left(\mathrm{SD}_{0}\right)$,

$$
\mathrm{L}_{\mathrm{C}}=\mathrm{t}_{1-\alpha \mathrm{df}} \times \mathrm{SD}_{0}
$$

using a $1 \%$ probability criterion for incorrectly stating that the analyte is present when in fact it is not, or conversely, stating that the analyte is not present, when it is in fact present. ${ }^{5,6}$ Data presented in Table 1 sets an $\mathrm{L}_{\mathrm{c}}$ value of $2.9 * 0.0205 \mathrm{ng}$ or $0.059 \mathrm{ng}-\mathrm{U}$ at 8 degrees of freedom for the ORNL procedure. In the current study using $10 \mathrm{~mL}$ of $2 \mathrm{M}\left(\mathrm{NH}_{4}\right)_{2} \mathrm{CO}_{3}-2 \mathrm{M} \mathrm{H}_{2} \mathrm{O}_{2}$ per sample, the Lc for the PNNL method is $6.965 * 0.0014 \mathrm{ng}$ (standard deviation of the first 3 entries in Table 3 ) or $0.0098 \mathrm{ng}-\mathrm{U}$ at 2 degrees of freedom.

The U mass assay of a full A080AK swipe (SwpBlkA-D) by the PNNL method averaged $2.35 \pm 0.094$ $(\mathrm{k}=2) \mathrm{ng}$, which is slightly higher than that found using the ORNL NWAL method and at other DOE facilities. This is an interesting finding since it had been assumed that the innate $\mathrm{U}$ content in a cotton swipe would not be amenable to the PNNL leaching process as compared to full combustion of the cotton swipe. Perhaps the accuracy of the PNNL result could be improved by lowering the dilution factor of the $\mathrm{U}$ in the leachate. The sample concentration aliquot in the ORNL fraction contains about 4 times more $\mathrm{U}$ than the PNNL fraction. This is due in part to the use of a full swipe in the ORNL protocol and the fact that the spiked aliquot is dried down to concentrate the U. It appears that introduction of undiluted $2 \mathrm{M}$

5. L. A. Currie, "Limits for qualitative detection and quantitative determination," Anal. Chem. 40, no. 3 (1968): 586-593.

6. L. A. Currie, "Detection: International update, and some emerging dilemmas involving calibration, the blank, and multiple detection decisions," Chemometrics and Intelligent Laboratory Systems 37 (1997): 151-181. 
$\left(\mathrm{NH}_{4}\right)_{2} \mathrm{CO}_{3}-2 \mathrm{M} \mathrm{H}_{2} \mathrm{O}_{2}$ (Table 3, entry CIMS No. 6G113) directly into the single sector ICPMS does not hinder sample analysis if the solution is introduced via a "wet" plasma system. However, operating in a "wet" plasma mode, that does not remove the aqueous matrix of the sample, results in a two orders of magnitude reduction in instrument sensitivity. The instrumental setup for $U$ mass determinations does not require desolvation of the sample matrix prior to introduction into the plasma. This implies that the $2 \mathrm{M}\left(\mathrm{NH}_{4}\right)_{2} \mathrm{CO}_{3}-2 \mathrm{M} \mathrm{H}_{2} \mathrm{O}_{2}$ sample leachate used for $\mathrm{U}$ concentration might be introduced into the ICPMS without significant sample dilution with $2 \% \mathrm{HNO}_{3}$.

Table 3. ORNL analysis of reagent blanks and half TX 304 cotton swipes (Lot no. A080AK) using the PNNL leachate method

\begin{tabular}{lcccccccc}
\hline \multicolumn{1}{c}{ Sample } & CIMS \# & $\begin{array}{c}\text { Dilution } \\
\text { Factor }\end{array}$ & $\begin{array}{c}\text { 233 U Spike, } \\
\text { ng }\end{array}$ & ng-U & 1 Sigma & Units & $\begin{array}{c}{ }^{235} \mathbf{U} /{ }^{238} \mathbf{U} \\
\text { At. Ratio }\end{array}$ & 1 Sigma \\
\hline ChemBlkA & $6 \mathrm{~B} 092$ & 9.663781 & 1.562014 & $1.7 \mathrm{E}-03$ & $1.9 \mathrm{E}-04$ & $\mathrm{ng} / 5 \mathrm{~mL}$ & & \\
ChemBlkB & $6 \mathrm{~B} 093$ & 9.662563 & 1.546143 & $8.6 \mathrm{E}-04$ & $2.0 \mathrm{E}-03$ & $\mathrm{ng} / 5 \mathrm{~mL}$ & & \\
ChemBlkC & $6 \mathrm{~B} 094$ & 9.663686 & 1.537292 & $2.3 \mathrm{E}-03$ & $1.9 \mathrm{E}-04$ & $\mathrm{ng} / 5 \mathrm{~mL}$ & & \\
SwpblkA & $6 \mathrm{~B} 095$ & 19.55765 & 1.55713 & $1.16 \mathrm{E}+00$ & $5.0 \mathrm{E}-01$ & $\mathrm{ng} / \mathrm{sample}$ & 0.00742 & 0.00322 \\
SwpblkB & $6 \mathrm{~B} 096$ & 19.50367 & 1.558656 & $1.21 \mathrm{E}+00$ & $1.3 \mathrm{E}-01$ & $\mathrm{ng} / \mathrm{sample}$ & 0.00744 & 0.00077 \\
SwpblkC & $6 \mathrm{~B} 097$ & 19.6341 & 1.554078 & $1.16 \mathrm{E}+00$ & $1.1 \mathrm{E}-01$ & $\mathrm{ng} / \mathrm{sample}$ & 0.00742 & 0.00065 \\
SwpblkD & $6 \mathrm{~B} 098$ & 19.62433 & 1.554078 & $1.17 \mathrm{E}+00$ & $1.5 \mathrm{E}-01$ & ng/sample & 0.00732 & 0.00099 \\
$2 \% \mathrm{HNO}_{3} \mathrm{~A}$ & $6 \mathrm{G} 099$ & 1 & 1.535461 & $5.6 \mathrm{E}-05$ & $6.0 \mathrm{E}-05$ & & & \\
$2 \% \mathrm{HNO}_{3} \mathrm{~B}$ & $6 \mathrm{G} 100$ & 1 & 1.537292 & $1.6 \mathrm{E}-05$ & $2.4 \mathrm{E}-06$ & & & \\
$\left(\mathrm{NH}_{4}\right)_{2} \mathrm{CO}_{3}-\mathrm{H}_{2} \mathrm{O}_{2}$ & $6 \mathrm{G} 113$ & 1 & 0 & 0 & NA & & 0.002 & 0.018 \\
\hline
\end{tabular}

\subsubsection{Experiment 1 Summary}

In this limited study, the background $U$ concentration extracted from the cotton TexWipe TX304 samples appears quite similar between the ORNL and PNNL protocols. The significant difference is the 15 days required to digest and chemically process a swipe using the ORNL NWAL procedure as compared to the 1 day required to digest and chemically process a wipe using the PNNL leachate procedure. The calculated Lc of the ORNL NWAL method is slightly higher, most likely due to additional chemical processing steps. The accuracy is slightly better for the ORNL protocol because it relies on concentrating the U sample mass by evaporation. In the PNNL process, the U mass is diluted by a factor of $10-25$, the amount of carbonate leachate required to completely immerse a folded swipe. The ${ }^{235} \mathrm{U} /{ }^{238} \mathrm{U}$ ratio did not appear to be perturbed by the presence of $2 \mathrm{M}\left(\mathrm{NH}_{4}\right)_{2} \mathrm{CO}_{3}-2 \mathrm{M} \mathrm{H}_{2} \mathrm{O}_{2}$ in the ICPMS. The minor $\mathrm{U}$ isotope ratios could not be determined directly in the $2 \mathrm{M}\left(\mathrm{NH}_{4}\right)_{2} \mathrm{CO}_{3}-2 \mathrm{M} \mathrm{H}_{2} \mathrm{O}_{2}$ matrix with minimal dilution of the leachate salt content. Follow on experiments explored the measurement of minor U isotopic ratios using a desolvating nebulizer introduction system in conjunction with an MC-ICPMS to determine whether they could also be accurately measured using the PNNL leachate method.

\subsection{EXPERIMENT 2: DETERMINATION OF BLANK U LEVELS IN TEXWIPE TX304 (LOT A080AK) COTTON SWIPES AND THREE SYNTHETIC SWIPES USING $2 \mathrm{M}\left(\mathrm{NH}_{4}\right)_{2} \mathrm{CO}_{3^{-}}$ $2 \mathrm{M} \mathrm{H}_{2} \mathrm{O}_{2}$ PROTOCOL}

\subsubsection{Experiment 2 Objective}

The blank $U$ levels and isotopic composition of reagents, an IAEA swipe, and the three synthetic materials were compared using the full ORNL NWAL separation protocol and the carbonate method developed by PNNL. Prior to receipt at ORNL, the synthetic materials had been washed in $6 \mathrm{M} \mathrm{HNO}_{3}$ at 
PNNL and cut into 2 inch by 4 inch swatches. In Experiment 2, three reagent blanks and three swipes of each test material were processed using a similar procedure as described in Experiment 1.

\subsubsection{Experiment 2 Procedure}

The testing differences between Experiment 1 and Experiment 2 were: 1) $10 \mathrm{~mL}$, rather than $5 \mathrm{~mL}$, reagent blanks were prepared to match sample leachate volumes; 2) the final sample leachates were not diluted with $2 \% \mathrm{HNO}_{3}$ prior to ICPMS analysis; and 3) an attempt was made to analyze minor isotopic ratios in the carbonate matrix on an MC-ICPMS. A companion study was also performed using the full ORNL ashing and chemical protocol to compare $U$ mass and isotopic data with that acquired using the PNNL leachate procedure.

\subsubsection{Experiment 2 Results}

\section{Swipes Processed by PNNL Protocol}

A. Extraction. The handling of Zorflex ${ }^{\circledR}$ FM $50 \mathrm{~K}$ carbon fabric resulted in the nitrile gloves and work area being coated with a fine carbon covering (Figure 3). When Zorflex ${ }^{\circledR}$ FM $50 \mathrm{~K}$ carbon fabric was contacted with the $2 \mathrm{M}\left(\mathrm{NH}_{4}\right)_{2} \mathrm{CO}_{3}-2 \mathrm{M} \mathrm{H}_{2} \mathrm{O}_{2}$ leachate, it reacted aggressively for at least 10 minutes, producing copious amounts of gas and heat. The effervescence generated from the reaction, along with significant sloughing of carbon fibers, suggest that this material will be a problem for contamination control during the handling of a loaded swipe and most likely would not be acceptable for use in a clean room.

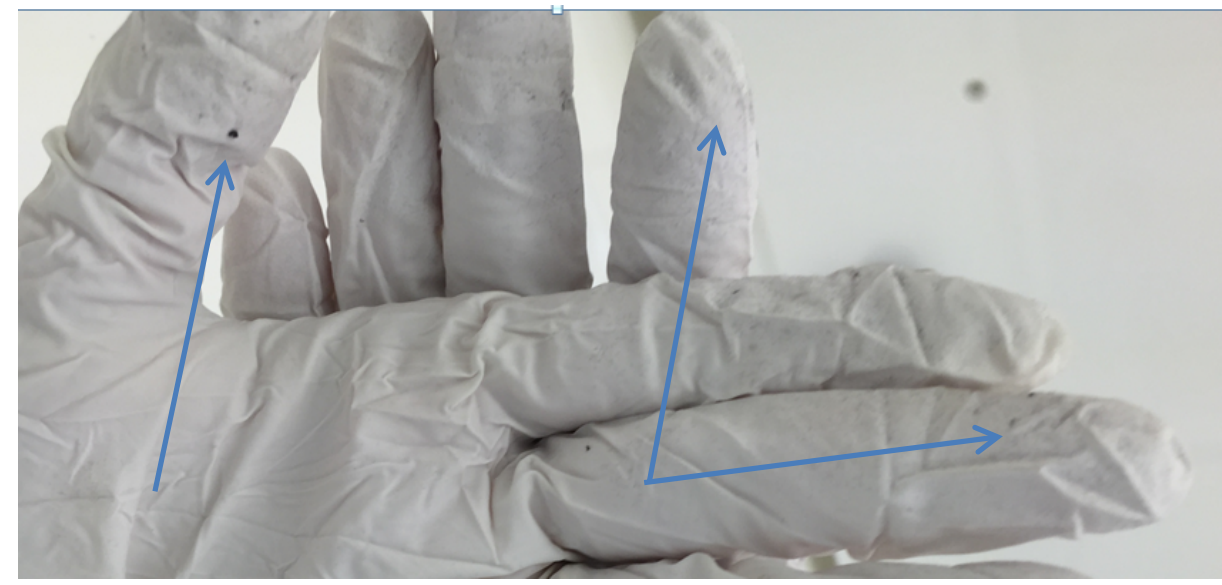

Figure 3. Loose carbon fibers produced in handling of the Zorflex® FM 50K carbon fabric.

B. Instrumental analysis. Samples processed by the leachate method were submitted as-prepared in $2 \mathrm{M}$ $\left(\mathrm{NH}_{4}\right)_{2} \mathrm{CO}_{3}-2 \mathrm{M} \mathrm{H}_{2} \mathrm{O}_{2}$ for MC-ICPMS analysis. No significant solid carbonate buildup was observed when introducing this solution matrix into a "wet" plasma of a single sector Element 2 using an ESI $\mathrm{PC}^{3}$ sample introduction system. However, an ESI PFA introduction system is typically used on the MC-ICPMS to create a "dry" plasma that improves the instrumental sensitivity required for measuring minor isotopic ratios. Use of a "dry" introduction produced significant carbonate buildup and plugged the introduction system almost immediately, even when the leachates were diluted by a factor of ten with $2 \% \mathrm{HNO}_{3}$. As seen in Figure 4, significant carbon buildup was observed on the instrument cones after the introduction of just 15 samples. 
An attempt was made to analyze the leachate samples on an MC-ICPMS fitted with a "wet" ESI PC 3 nebulizer. If the leachate was diluted by a factor of two with $2 \% \mathrm{HNO}_{3}$, three samples could be measured at a time before the nebulizer plugged with carbonate salt. Additionally, a loss of in sensitivity by a factor of 15 was observed when using a "wet" plasma, and, therefore, count rates of minor $\mathrm{U}$ isotopics were below detection limits for the MC-ICPMS.

C. Results. Table 4 summarizes the quantity of $\mathrm{U}$ extracted from the various swipe materials by $2 \mathrm{M}$ $\left(\mathrm{NH}_{4}\right)_{2} \mathrm{CO}_{3}-2 \mathrm{M} \mathrm{H}_{2} \mathrm{O}_{2}$. As indicated in Table 4, the count rate of ${ }^{235} \mathrm{U}$, let alone ${ }^{234} \mathrm{U}$ and ${ }^{236} \mathrm{U}$, is too low to determine the ${ }^{235} \mathrm{U} / 238 \mathrm{U}$ ratio. The Zorflex ${ }^{\circledR}$ FM $50 \mathrm{~K}$ was diluted by a factor of 50 prior to analysis to protect the instrument detector from high $U$ and fiber content of this particular swipe material. The Texwipe TX304 cotton swipe contained about four times more background $U$ than the PTFE-coated fiberglass and RCF carbon tissue leachates.

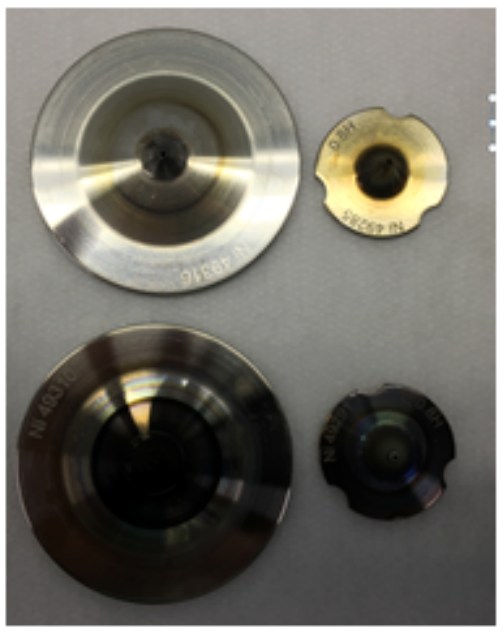

The first set of cones were used to analyze 76 IAEA samples with ORNL NWAL protocol. Both the sample and skimmer cones are clean with minimal discoloration. The skimmer cone orifice remains crisp, and clean without material build up.

The cones used for 15 carbonate samples show heavy carbon deposits on the sampler cone surface. The skimmer cone has heavy deposits on the tip, and showed "ion burn" or "bluing" from the high total dissolved solids in the samples.

Figure 4. Carbon coating of MC-ICPMS cones using a $2 \mathrm{M}\left(\mathrm{NH}_{4}\right)_{2} \mathrm{CO}_{3}-2 \mathrm{M}$ $\mathrm{H}_{2} \mathrm{O}_{2}$ sample matrix.

Table 4. $\mathrm{U}$ Isotopic and mass composition of 2 inch by 4 inch swipes treated with the $2 \mathrm{M}\left(\mathrm{NH}_{4}\right)_{2} \mathrm{CO}_{3}-2 \mathrm{M}$ $\mathrm{H}_{2} \mathrm{O}_{2}$ leachate method

\begin{tabular}{lcccccccc}
\hline \multicolumn{1}{c}{ Sample } & ${ }^{233} \mathbf{U}{ }^{238} \mathbf{U}$ & 2 Sigma & 235 counts & 2 Sigma & $\begin{array}{c}\text { 238 } \\
\text { counts }\end{array}$ & 2 Sigma & U, ng & $\begin{array}{c}\text { 2 Sigma, } \\
\text { ng }\end{array}$ \\
\hline Reagent Blank 1 & 1331 & 57 & -438 & 2205 & 1352 & 2704 & 0.00375 & 0.00016 \\
Reagent Blank 2 & 2977 & 154 & -735 & 1697 & 578 & 1155 & -0.00075 & 0.000038 \\
Reagent Blank 3 & 252.1 & 4.0 & -287 & 2562 & 7062 & 14125 & 0.02876 & 0.00039 \\
IAEA Cotton 1 & 8.285 & 0.13 & 445 & 2495 & 198347 & 396693 & 0.8682 & 0.00628 \\
IAEA Cotton 2 & 258.0 & 0.80 & 1317 & 2222 & 201041 & 402083 & 0.02938 & 0.00059 \\
IAEA Cotton 3 & 9.09 & 0.087 & 1255 & 2335 & 206242 & 412485 & 0.8552 & 0.0025 \\
PTFE Coated 1 & 43.08 & 0.37 & -347 & 2239 & 42359 & 84718 & 0.17040 & 0.00092 \\
PTFE Coated 2 & 41.81 & 0.36 & -350 & 2131 & 35499 & 70999 & 0.17853 & 0.00097 \\
PTFE Coated 3 & 52.75 & 0.59 & -103 & 2378 & 33926 & 67852 & 0.1410 & 0.0010 \\
RCF Carbon 1 & 65.14 & 0.72 & -216 & 2233 & 28207 & 56414 & 0.1128 & 0.00079 \\
RCF Carbon 2 & 57.37 & 0.64 & -242 & 2170 & 32071 & 64142 & 0.1287 & 0.00064 \\
RCF Carbon 3 & 61.49 & 0.60 & -378 & 2089 & 42760 & 85521 & 0.1220 & 0.00058 \\
\hline
\end{tabular}




\begin{tabular}{lllllrlrl}
\hline Zorflex Carbon 1 & 1.15 & 0.27 & -798 & 2360 & 17473 & 34945 & 6.5 & 1.6 \\
Zorflex Carbon 2 & 0.89 & 0.37 & -45 & 2664 & 8271 & 16542 & 8.7 & 3.7 \\
\hline
\end{tabular}

Unless the dissolved solids content of the leachates can be significantly reduced, high accuracy isotopic measurement cannot be conducted on an MC-ICPMS equipped with a high efficiency desolvating nebulizer. Previous process development testing by PNNL staff used U oxide particles to load swipe materials. Resulting leachate samples contained $U$ in the microgram range-levels several orders of magnitude higher than what is typically found in most IAEA samples. Therefore, PNNL test leachates were diluted by a factor of 200-300 to obtain U concentrations in a calibration curve range of a quadrapole (Q)-ICPMS. Consequently, the diluted leachate had a lower dissolved solids content that did not consistently plug the flow lines of the Q-ICPMS. Most NWAL ICPMS systems use an MC-ICPMS equipped with a high efficiency desolvating nebulizer to enable measurement of minor isotopic ratios at low $\mathrm{U}$ concentration. This type of instrument setup is more sensitive to salt/solid content in the sample matrix. Furthermore, most IAEA samples contain less than $100 \mathrm{ng}$ of Upreempting possible dilution of sample leachate. Consequently, ORNL and PNNL are exploring methods to reduce the solids content of the sample leachate to permit analysis by MC-ICPMS.

Several attempts were made at ORNL to decompose the carbonate solids, first by evaporating the $2 \mathrm{M}$ $\left(\mathrm{NH}_{4}\right)_{2} \mathrm{CO}_{3}-2 \mathrm{M}-\mathrm{H}_{2} \mathrm{O}_{2}$ followed by acidification of the residue with $8 \mathrm{M} \mathrm{HNO}_{3}$. This latter step most likely volatilized the carbonate but created ammonium nitrate solids. Ammonium carbonate was more successfully decomposed thermally by evaporating $2 \mathrm{M}\left(\mathrm{NH}_{4}\right)_{2} \mathrm{CO}_{3}-2 \mathrm{M} \mathrm{H}_{2} \mathrm{O}_{2}$ and then heating the residue in a tube furnace overnight at $250{ }^{\circ} \mathrm{C}$. The vial was then rinsed with $2 \% \mathrm{HNO}_{3}$ to collect the U followed by MC-ICPMS analysis using a "dry" nebulizer (Figure 5).

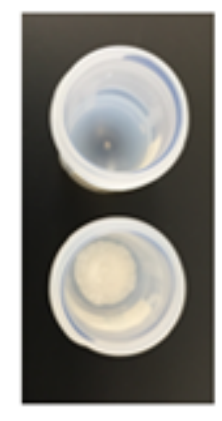

NWAL column chemistry creates a low dissolved solids fraction that is easily brought up in $2 \% \mathrm{HNO} 3$ and can be directly introduced into a MC-ICPMS.

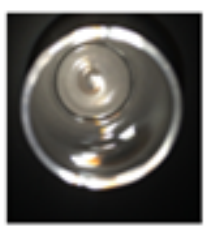

$\left(\mathrm{NH}_{4}\right)_{2} \mathrm{CO}_{3}$ can be thermally decomposed in a fumace. $2 \% \mathrm{HNO}_{3}$ can be used to collect sample uranium from the vial for analysis by MC-ICPMS.

Figure 5. NWAL column separations vs. leach processing.

As shown in Table 5, it was possible to determine minor isotopic abundances of thermally decomposed ammonium carbonate. Results indicate that the fired carbonate contained $U$ with natural isotopic compostion; no perturbation of minor $\mathrm{U}$ ratios was noted in the final treated aliquot. Approximately $0.002 \mathrm{ng}$ of $\mathrm{U}$ was found in $4 \mathrm{~mL}$ of $2 \mathrm{M}\left(\mathrm{NH}_{4}\right)_{2} \mathrm{CO}_{3}-2 \mathrm{M} \mathrm{H}_{2} \mathrm{O}_{2}$ leachate.

Table 5. Isotopic composition of $\mathrm{U}$ in thermally decomposed $2 \mathrm{M}\left(\mathrm{NH}_{4}\right)_{2} \mathrm{CO}_{3}-2 \mathrm{M} \mathrm{H}_{2} \mathrm{O}_{2}$ leachate

\begin{tabular}{lllllllll}
\hline Sample & ${ }^{233} U / 238 U$ & 2 Sigma & ${ }^{234} U / 238 U$ & 2 Sigma & ${ }^{235} U / 238 U$ & 2 Sigma & ${ }^{236} U / 238 U$ & 2 Sigma \\
\hline
\end{tabular}




\begin{tabular}{lllllllll}
\hline $\begin{array}{l}\left(\mathbf{N H}_{4}\right)_{2} \mathbf{C O}_{3} \\
\text { Blank }\end{array}$ & $5.85 \mathrm{E}-05$ & $5.1 \mathrm{E}-05$ & $8.1 \mathrm{E}-05$ & $3.7 \mathrm{E}-05$ & 0.007341 & $4.5 \mathrm{E}-04$ & $7.8 \mathrm{E}-05$ & $7.3 \mathrm{E}-05$ \\
\hline
\end{tabular}

\section{Swipes Processed by ORNL NWAL Procedure}

A. Dry ashing of swipes. Following full NWAL protocol, 4 inch by 4 inch TX304 cotton swipes and two each of 2 inch by 4 inch synthetic material swipes were folded multiple times and loaded into leached $65 \mathrm{~mL}$ Pyrex tubes. The RCF carbon fabric was particularly easy to load due to the stiffness of the matrix. Again, the Zorflex ${ }^{\circledR}$ FM $50 \mathrm{~K}$ material sloughed considerable amounts of fine fibers while folding and loading the swipe. Because of contamination concerns, this material was dropped from consideration for the Experiment 2 plan.

Ash resulting from the standard cotton swipe is light, fluffy, and easily dispersed within the ashing tube; the slightest static charge easily dispersed the ash during handling (Figure 6). The tube containing the PTFE-coated fiberglass was covered with a white film. The fiberglass fabric support remained intact after ashing. The RCF tissue left a fine ash on the inside of the tube resembling the pattern of folded swipe. The ash remained coherent, not breaking apart while the tube was transferred to a cleanroom.

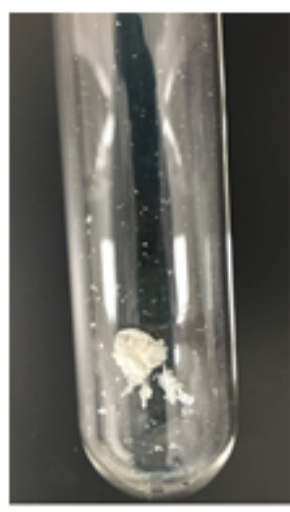

a

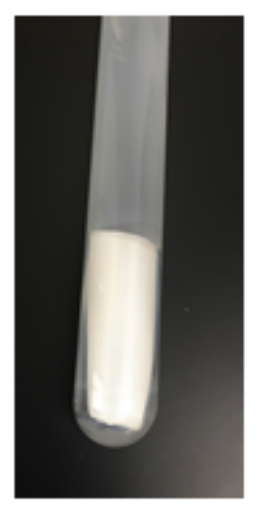

b

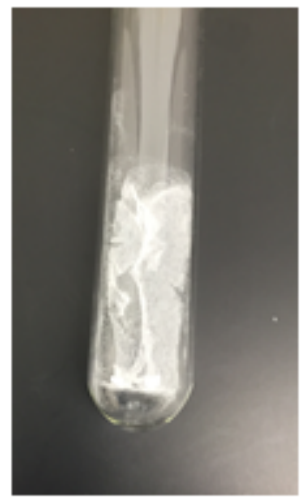

c

Figure 6. Ashed cotton (a), fiberglass (b), and RCF tissue (c).

B. Wet ashing of swipes. Ash residues from the three swipe matrices were transferred to PFA vials using a total of $10 \mathrm{~mL}$ of $3 \mathrm{M} \mathrm{HNO}_{3}$. The cotton ash produced a very light suspension containing a few remaining cotton fibers. The $3 \mathrm{M} \mathrm{HNO}_{3}$ completely removed the ash from the tube containing RCF; a fine silt was found in the RCF acid leachate. The acid washed the white film from the tubes containing ashed PTFE fiberglass. At least $1 \mathrm{~mL}$ of $3 \mathrm{M} \mathrm{HNO}_{3}$ remained entrained in the ashed fiberglass fabric in such a way that it could not be transferred to a vial.

At the completion of wet ashing with $3 \mathrm{M} \mathrm{HNO}_{3}-\mathrm{HF}$ and $3 \mathrm{M} \mathrm{HNO}_{3}-\mathrm{H}_{2} \mathrm{O}_{2}$, all swipe materials produced around 1-2 milligrams of solids upon dry down. The solids dissolved easily in $1 \mathrm{~mL}$ of $3 \mathrm{M}$ $\mathrm{HNO}_{3}$ and could subsequently be loaded onto Eichrom UTEVA columns. The final purified column fractions contained little to no solids upon evaporation (Figure 5).

C. Instrumental analysis. Final column fractions were submitted in $2 \%(\mathrm{w} / \mathrm{w}) \mathrm{HNO}_{3}$, creating no instrumental problems when introduced to an MC-ICPMS that was equipped with a high-efficiency desolvating nebulizer. 
D. Results for NWAL Procedure. Isotopic composition and U mass of swipes processed using the ORNL NWAL procedure are presented in Table 6 . The NWAL procedure works quite well for determining $\mathrm{U}$ mass and concentration for all swipe matrices. It is evident that the PTFE-coated fiberglass contains higher natural background $U$ than other swipe materials at a level that would diminish its use for low level IAEA bulk environmental analysis. All isotopic signatures are equivalent to that of natural $U$, with the exception of the fiberglass swipes which have slightly elevated ${ }^{235} U / 238 U$ ratios. The ${ }^{234} \mathrm{U}$ isotope is slightly enriched in cotton swipes due to the elevated concentration of this particular isotope in the soils from which the cotton is grown. The RCF carbon tissue had slightly elevated ${ }^{234} \mathrm{U} /{ }^{238} \mathrm{U}$ ratios. 
Table 6. U Isotopic and mass composition of 4 inch by 4 inch swipes treated using ORNL NWAL procedure

\begin{tabular}{|c|c|c|c|c|c|c|c|c|c|c|}
\hline Sample & ${ }^{233} U /{ }^{238} U$ & 2 Sigma & ${ }^{234} U /{ }^{238} U$ & 2 Sigma & ${ }^{235} U /{ }^{238} U$ & 2 Sigma & ${ }^{236} \mathbf{U} /{ }^{238} \mathbf{U}$ & 2 Sigma & U, ng & 2 Sigma, ng \\
\hline Reagent Blank 1 & $1.26 \mathrm{E}-03$ & $1.0 \mathrm{E}-04$ & $7.7 \mathrm{E}-05$ & $1.3 \mathrm{E}-05$ & 0.011324 & 0.000167 & $2.25 \mathrm{E}-03$ & $1.1 \mathrm{E}-04$ & 0.0066 & 0.00050 \\
\hline Reagent Blank 2 & $2.00 \mathrm{E}-04$ & $3.9 \mathrm{E}-05$ & $8.2 \mathrm{E}-05$ & $1.7 \mathrm{E}-05$ & 0.009899 & 0.000179 & $1.61 \mathrm{E}-04$ & $4.0 \mathrm{E}-05$ & 0.0089 & 0.00088 \\
\hline Reagent Blank 3 & $6.0 \mathrm{E}-05$ & $2.2 \mathrm{E}-05$ & $8.4 \mathrm{E}-05$ & $1.5 \mathrm{E}-05$ & 0.007816 & 0.000142 & $5.1 \mathrm{E}-05$ & $1.7 \mathrm{E}-05$ & 0.0176 & 0.00055 \\
\hline IAEA Cotton 1 & $3.46 \mathrm{E}-06$ & $5.2 \mathrm{E}-07$ & $7.22 \mathrm{E}-05$ & $2.2 \mathrm{E}-06$ & 0.007286 & $2.4 \mathrm{E}-05$ & $1.15 \mathrm{E}-06$ & $3.0 \mathrm{E}-07$ & 1.800 & 0.0028 \\
\hline IAEA Cotton 2 & $1.92 \mathrm{E}-06$ & $3.4 \mathrm{E}-07$ & 7.23E-05 & $1.7 \mathrm{E}-06$ & 0.007296 & $2.73 \mathrm{E}-05$ & $1.50 \mathrm{E}-06$ & 3.3E-07 & 1.913 & 0.0013 \\
\hline IAEA Cotton 3 & $1.13 \mathrm{E}-06$ & $2.9 \mathrm{E}-07$ & $7.24 \mathrm{E}-05$ & $1.9 \mathrm{E}-06$ & 0.007277 & $3.6 \mathrm{E}-05$ & $6.3 \mathrm{E}-07$ & $2.4 \mathrm{E}-07$ & 1.756 & 0.0020 \\
\hline PTFE Coated 1 & $2.70 \mathrm{E}-06$ & $3.9 \mathrm{E}-07$ & $5.59 \mathrm{E}-05$ & $1.9 \mathrm{E}-06$ & 0.007293 & $3.51 \mathrm{E}-05$ & $3.5 \mathrm{E}-07$ & $2.1 \mathrm{E}-07$ & 11.233 & 0.014 \\
\hline PTFE Coated 2 & $4.12 \mathrm{E}-07$ & 3.7E-07 & $5.62 \mathrm{E}-05$ & 2.7E-06 & 0.007328 & $2.87 \mathrm{E}-05$ & $-4 \mathrm{E}-08$ & 4.7E-07 & 8.446 & 0.0050 \\
\hline PTFE Coated 3 & $6.23 \mathrm{E}-06$ & $6.0 \mathrm{E}-07$ & $5.65 \mathrm{E}-05$ & $2.2 \mathrm{E}-06$ & 0.007358 & $3.3 \mathrm{E}-05$ & $8.1 \mathrm{E}-07$ & 4.0E-07 & 10.631 & 0.0092 \\
\hline RCF Carbon 1 & 7.19E-04 & $8.4 \mathrm{E}-06$ & $6.49 \mathrm{E}-05$ & $2.1 \mathrm{E}-06$ & 0.007668 & $3.3 \mathrm{E}-05$ & $3.07 \mathrm{E}-06$ & $7.1 \mathrm{E}-07$ & 0.444 & 0.0024 \\
\hline RCF Carbon 2 & $9.79 \mathrm{E}-05$ & $3.0 \mathrm{E}-06$ & $6.09 \mathrm{E}-05$ & $3.0 \mathrm{E}-06$ & 0.007282 & $3.4 \mathrm{E}-05$ & $5.72 \mathrm{E}-06$ & $8.0 \mathrm{E}-07$ & 0.4346 & 0.00080 \\
\hline RCF Carbon 3 & $2.54 \mathrm{E}-05$ & $1.7 \mathrm{E}-06$ & $6.34 \mathrm{E}-05$ & $3.3 \mathrm{E}-06$ & 0.007513 & 4.3E-05 & $2.47 \mathrm{E}-06$ & $5.9 \mathrm{E}-07$ & 0.457 & 0.013 \\
\hline
\end{tabular}




\subsection{EXPERIMENT 3: REDUCING SALT CONTENT IN PNNL LEACHATE TO OVERCOME CARBONATE DEPOSITION}

\subsubsection{Experiment 3 Objective}

The Achilles heel of the PNNL leachate procedure for high precision isotopic measurements is its high salt content, which tends to plug the flow of a desolvating nebulizer. Post treatment of $2 \mathrm{M}\left(\mathrm{NH}_{4}\right) 2 \mathrm{CO}_{3}-2 \mathrm{M} \mathrm{H}_{2} \mathrm{O}_{2}$ - in order to reduce suspended solids in a sample leachate by heating or ashing - extends the sample preparation time by at least 24 hours. Another option might be to significantly reduce the concentration of the leachate with the hope that the leachate can then be introduced directly into an MC-ICPMS equipped with a desolvating nebulizer without affecting the recovery of sample $\mathrm{U}$. A leachate concentration of $5 \mathrm{E}-04 \mathrm{M}\left(\mathrm{NH}_{4}\right)_{2} \mathrm{CO}_{3}-2 \mathrm{M} \mathrm{H}_{2} \mathrm{O}_{2}$ is equivalent to the $0.005 \%$ manufacturer's limit for dissolved solids that can be introduced into a desolvating nebulizer. However, it remains to be seen whether this leachate concentration will have sufficient complexing strength to extract $U$ from exposed swipes.

The objective of Experiment 3 was to determine if a leachate concentration greater than $5 \mathrm{E}-04 \mathrm{M}$ $\left(\mathrm{NH}_{4}\right)_{2} \mathrm{CO}_{3}-2 \mathrm{M} \mathrm{H}_{2} \mathrm{O}_{2}$ could be directly analyzed using a MC-ICPMS equipped with a "wet" sample introduction system. If a stronger leach concentration is required, then the ammonium carbonate leachate protocol might be applied to samples containing $>100 \mathrm{ng}$ total $\mathrm{U}$ where sufficient count rates of minor isotopes might be possible. The upper concentration limit of ammonium carbonate content in leachate solution for a "wet" sample introduction system was determined by directly introducing 1E-08 $\mathrm{M}$ up to $0.2 \mathrm{M}$ of $\left(\mathrm{NH}_{4}\right)_{2} \mathrm{CO}_{3}$ in $2 \mathrm{M} \mathrm{H}_{2} \mathrm{O}_{2}$ into an ICPMS equipped with a glass nebulizer. As is characteristic of glass nebulizers, the liquid drain hole is $1 / 4$ inch inside diameter (Figure 7) such that it can accommodate a modicum of solids deposition without plugging. Ten aliquots of each half-decade leachate concentration were analyzed consecutively to mimic the number of samples analyzed in a typical ICPMS sample run sequence. Acid rinses were interspersed between each carbonate aliquot, as is typical of a standard sample sequence setup.

Experiment 3 Results. It appears that blockage of a "wet" nebulizer occurs at near the same $0.005 \%$ dissolved solids limit specified by the manufacturer-5E-04 $\mathrm{M}\left(\mathrm{NH}_{4}\right)_{2} \mathrm{CO}_{3}$. Above this concentration, consistent instrument operation became problematic. Carbon deposition on instrument cones similar to that depicted in Figure 4 was observed.

Now that an upper limit for leachate concentration has been established for instrument operation, it remains to be seen how $5 \mathrm{E}-04 \mathrm{M}\left(\mathrm{NH}_{4}\right)_{2} \mathrm{CO}_{3}$ will affect the efficient recovery of sample $\mathrm{U}$ as well as its ability to complex metallic elements such as $\mathrm{Pb}, \mathrm{W}$, etc. that might perturb the isotopic signature of the $\mathrm{U}$. 


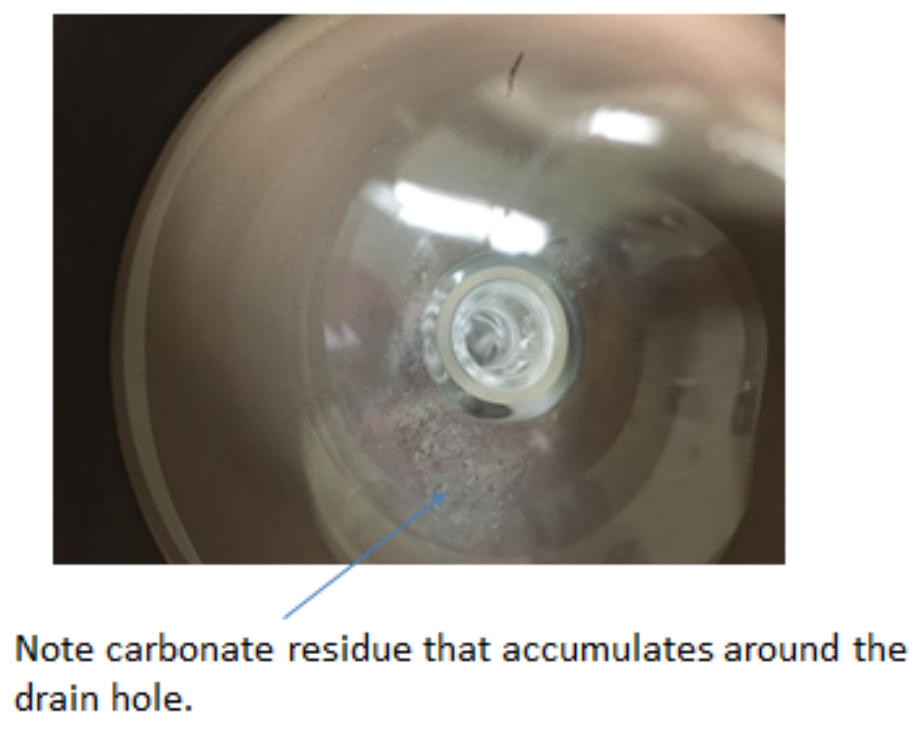

Figure 7. Interior of a "wet" glass nebulizer.

\subsection{OVERALL SUMMARY}

IAEA NWAL analysis is predicated on obtaining high-accuracy, high-precision isotopic composition in samples typically containing $0.5-100 \mathrm{ng} \mathrm{U}$ and $0.01-10 \mathrm{pg}$ Pu. To accomplish this task using MCICPMS, actinides must be concentrated and separated from organic and/or inorganic contaminants that might form molecular isobaric interferences in the U-Pu isotope mass range. Both the collection media and the chemical processing required for actinide isolation must be ideal to meet IAEA requirements. This study looked at several synthetic swipe materials and an alternative chemical processing procedure based on carbonate extraction to determine whether IAEA U measurement goals could be accomplished in a more timely and cost efficient manner than current NWAL sampling and processing protocols. The results of this study are summarized below.

\subsubsection{Evaluation of Swipe Materials}

IAEA swipe materials are selected based on several characteristics. Among these are: 1) the amount and consistency of background $U$ content in the material, 2) the efficiency of collection and retrieval of sample U from swipe surfaces, and 3) the physical handling characteristics of the material. There would be added value if the swipe material could function as the support for sample $U$ in alternative measurement equipment such as in a SIMS. The TX304 swipe has been selected by IAEA because the base material (cotton) is only grown in a single location (southeast United States) and is cleaned in a cleanroom environment. Manufacturing lots of TX304 are selected for low U content and distributed to IAEA inspectors for sample collection. The $U$ isotopic abundance of the latent $U$ is consistent, as stated in Table 1. The cotton has a sturdy twill weave that maintains its physical integrity even when used to wipe rough surfaces. Cotton can be destroyed by thermal or chemical ashing so that sample actinides can be readily collected and chemically purified for subsequent instrumental analysis.

Synthetic swipes in conjunction with ORNL NWAL protocol. Although not necessary for the carbonate leaching method, ORNL procedure requires thermal ashing to destroy the swipe matrix. A comparison of intrinsic U content in three synthetic swipe materials (PTFE-coated fiberglass, RCF carbon tissue, and Zorflex ${ }^{\circledR}$ FM $50 \mathrm{~K}$ carbon fiber fabric) was initiated by ashing at $600{ }^{\circ} \mathrm{C}$. Ashed fiberglass swipes contained an average of $10 \mathrm{ng}$ natural $\mathrm{U}$, and carbon tissue swipes contained an average of $0.44 \mathrm{ng}$ natural U. A value could not be obtained for Zorflex ${ }^{\circledR}$ FM $50 \mathrm{~K}$ because it was dropped from the study due to its 
tendency to shed a high volume of fine carbon particles. Neither the PTFE-coated fiberglass nor the RCF carbon tissue shed significantly. RCF carbon ashed completely. However, on the PTFE-coated fiberglass only the polytetrafluoroethylene coating ashed while the fiberglass did not. Hence, particles might be trapped within its folds when using an acid wash to transfer sample particulates from the ashing tube. It may be necessary to unfold and rinse the ashed fiberglass to efficiently collect particulates. A concern with the RCF carbon is that a higher density felt rather than carbon tissue should be tested for field use since the tissue might easily tear while wiping rough surfaces.

Synthetic swipes in conjunction with carbonate leaching protocol. The significant finding among the three synthetic wipes was that the Zorflex ${ }^{\circledR}$ FM $50 \mathrm{~K}$ fabric reacted vigorously and exothermally with $2 \mathrm{M}$ $\left(\mathrm{NH}_{4}\right)_{2} \mathrm{CO}_{3}-2 \mathrm{M} \mathrm{H}_{2} \mathrm{O}_{2}$. Thus, it might create a safety issue in capped vials or a contamination issue in an uncapped vial because of the significant effervescence of the reaction. The PTFE-coated fiberglass and RCF carbon tissue leachates contained about a factor of four less background $\mathrm{U}$ compared to the Texwipe TX304 cotton swipe. The less aggressive $2 \mathrm{M}\left(\mathrm{NH}_{4}\right)_{2} \mathrm{CO}_{3}-2 \mathrm{M} \mathrm{H}_{2} \mathrm{O}_{2}$ extraction removed only $10 \%$ of latent $\mathrm{U}$ in the PTFE-coated fiberglass compared to that found if this particular material was ashed in a furnace.

\subsubsection{Evaluation of Chemical Processing of Swipes}

ORNL NWAL protocol is designed to destroy a cotton swipe matrix along with organic constituents, to isolate actinides from concomitant inorganic impurities, and to concentrate $\mathrm{U}$ and $\mathrm{Pu}$ fractions for $\mathrm{MC}$ ICPMS. Although time consuming, the standard protocol meets the treaty verification needs for the IAEA. For alternative procedures to be considered, basic IAEA analysis requirements must be met in addition to providing significant advantages in actinide measurement, analysis time, and/or cost savings. The $2 \mathrm{M}\left(\mathrm{NH}_{4}\right)_{2} \mathrm{CO}_{3}-2 \mathrm{M} \mathrm{H}_{2} \mathrm{O}_{2}$ leachate method was evaluated on the basis of these terms.

$U$ content in reagent blanks. In the case of the ORNL NWAL procedure, the reagent U blank content is an aggregate of residue from ashing, multiple acid exchanges, and evaporation of the final purified eluant from a UTEVA column. The residue is brought up in $1.5 \mathrm{~mL}$ of $2 \% \mathrm{HNO}_{3}$ and submitted for analysis. The reagent blank in the carbonate protocol is simply the amount of $U$ found in $10 \mathrm{~mL}$ of $2 \mathrm{M}\left(\mathrm{NH}_{4}\right)_{2} \mathrm{CO}_{3}-2 \mathrm{M} \mathrm{H}_{2} \mathrm{O}_{2}$. Data from Tables 3 and 4 were used to compute entries for carbonate leaching data in Table 7. The critical limit (Lc) for both methods is stated at an error uncertainty of $1 \%$. The number of blanks (n) used to calculate the degrees of freedom are listed for each analysis method. The $\mathrm{U}$ blank level is slightly lower in the leaching procedure but is accompanied by a high uncertainty due to the difficultly of introducing $2 \mathrm{M}\left(\mathrm{NH}_{4}\right)_{2} \mathrm{CO}_{3}-2 \mathrm{M} \mathrm{H}_{2} \mathrm{O}_{2}$ into an MC-ICPMS.

Table 7. Comparison of reagent blanks generated by ORNL NWAL and Carbonate Leach methods

\begin{tabular}{lcc}
\hline & ORNL NWAL $(\mathbf{n}=\mathbf{9})$ & Carbonate leach $(\mathbf{n}=\mathbf{6})$ \\
\hline Reagent Blank U, ng & $2.9 \mathrm{E}-02$ & $7 \mathrm{E}-03$ \\
Reagent Blank U 2 $\boldsymbol{\sigma}, \mathbf{n g}$ & $4.1 \mathrm{E}-02$ & $2.0 \mathrm{E}-02$ \\
Method Lc, $\mathbf{n g}-\mathbf{U}$ & $5.9 \mathrm{E}-02$ & $3.3 \mathrm{E}-02$ \\
\hline
\end{tabular}

Analysis of $U$ content in 4 inch by 4 inch swipe blank materials. Because a swipe is destroyed by thermal ashing, the total amount of $U$ in a swipe fabric is collected in chemical processing using the ORNL NWAL protocol. Only leachable $U$ is collected in the carbonate leach method, primarily from the surface of fabric fibers. Therefore, $\mathrm{U}$ content in blank swipes is lower in the carbonate extracts. For example, while the PTFE-coated fiberglass is problematic if ashed, it creates a low $\mathrm{U}$ background if leached. The RCF graphite tissue appears to be a promising candidate for both chemical processing protocols. 
Zorflex ${ }^{\circledR}$ FM $50 \mathrm{~K}$ carbon fiber fabric is not amenable for either processing method. Table 8 shows a comparison of the swipe blanks and leach methods.

Table 8. Comparison of 4 inch by 4 inch swipe blanks generated by ORNL NWAL and Carbonate Leach methods

\begin{tabular}{lcccc}
\hline \multicolumn{1}{c}{ Sample } & NWAL ng-U & 2 Sigma & Carbonate Leach, ng-U & 2 Sigma \\
\hline IAEA Cotton 1 & 1.800 & 0.0028 & 1.7364 & 0.01256 \\
IAEA Cotton 2 & 1.913 & 0.0013 & NA & NA \\
IAEA Cotton 3 & 1.756 & 0.0020 & 1.7104 & 0.005 \\
PTFE Coated 1 & 11.233 & 0.014 & 0.3408 & 0.00184 \\
PTFE Coated 2 & 8.446 & 0.0050 & 0.35706 & 0.00194 \\
PTFE Coated 3 & 10.631 & 0.0092 & 0.282 & 0.002 \\
RCF Carbon 1 & 0.444 & 0.0024 & 0.2256 & 0.00158 \\
RCF Carbon 2 & 0.4346 & 0.00080 & 0.2574 & 0.00128 \\
RCF Carbon 3 & 0.457 & 0.013 & 0.244 & 0.00116 \\
Zorflex Carbon 1 & NA & NA & 13 & 3.2 \\
Zorflex Carbon 2 & NA & NA & 17.4 & 7.4 \\
\hline
\end{tabular}

NA: not analyzed

Analysis of $U$ isotopic abundances. The impact of a matrix containing high dissolved solids content on the ability to determine actinide isotopic distributions with an MC-ICPMS analysis is significant. A desolvating membrane is typically coupled with the instrument's sample introduction line to enable the measurement sensitivity required for analysis of minor $U$ isotopes for sample aliquots containing a few ng of U. A loss in sensitivity by a factor of about 15 is observed without a desolvating nebulizer, making it impossible to measure U isotopic ratios in low-level IAEA samples. Operation with a desolvating membrane limits dissolved solid content in a sample matrix to $0.005 \%$ or no greater than $5 \mathrm{E}-04 \mathrm{M}$ $\left(\mathrm{NH}_{4}\right)_{2} \mathrm{CO}_{3}$. This limitation requires dilution by a factor of at least 4000 of $2 \mathrm{M}\left(\mathrm{NH}_{4}\right)_{2} \mathrm{CO}_{3}-2 \mathrm{M} \mathrm{H}_{2} \mathrm{O}_{2}$ leachates prior to analysis by MC-ICPMS. PNNL staff members are determining whether a significantly lower carbonate concentration can still effectively collect sample $U$ so that the resulting sample leachate can be introduced directly into a high-precision MC-ICPMS without preliminary dilution.

If thermal ionization mass spectrometry (TIMS) instrumentation is to be considered, further dilution will be required so that the sample matrix does not significantly affect the ionization efficiency of sample actinides. An alternative to sample dilution is to evaporate carbonate extracts and fire them in a furnace to decompose the carbonate precipitate. The $\mathrm{U}$ can then be collected in $2 \%(\mathrm{w} / \mathrm{w}) \mathrm{HNO}_{3}$ and analyzed using standard high precision MC-ICPMS.

Additional processing considerations. The carbonate leaching procedure is a less aggressive technique that can be used to selectively extract non-refractory U compounds. The ORNL NWAL method dissolves and captures all compounds of $U$ present in the sample and the swipe matrix. In this scenario, the sample $\mathrm{U}$ isotopic composition is down blended by the latent $\mathrm{U}$ background in the swipe. Additionally, the carbonate methods cuts the time required for measurement of $U$ mass in loaded swipes. However, to make an accurate comparison of leaching versus NWAL processing times, it must be noted that the carbonate method does not incorporate splitting the leachate to create an unspiked aliquot for analysis of ${ }^{233} \mathrm{U} /{ }^{238} \mathrm{U}$ and a spiked aliquot for analysis of $U$ concentration. Spiking and equilibration of the ${ }^{233} U$ spike isotope with sample $U$ requires double heating and evaporation to ensure that the spike and sample $U$ isotopes are in the same chemical form for isotope dilution (ID) measurement of $U$ mass. Additionally, the carbonate method relies on the insolubility of carbonate contaminates to provide a separation of $U$ from elements 
that form molecular isobaric interferences. However, in the case of $\mathrm{Pb}$ contaminants, the carbonate is often colloidal and therefore may still be present in a filtered sample or be decomposed in a plasma to form $\mathrm{Pb}$ molecular interferences in the $\mathrm{U}$ and $\mathrm{Pu}$ mass range. ${ }^{7,8,9}$ The acidic matrix used in the NWAL method, along with the chromatographic separation of actinides, isolates $U$ from inorganic constituents commonly present in IAEA samples, and therefore isotopic analysis is not affected by concomitant species. The impact of metallic/organic contaminants on $\mathrm{U}$ isotopic analysis thus needs to be addressed for the leachate method.

\subsection{RECOMMENDATIONS}

RCF carbon tissue appears to hold the most promise as an alternative swipe material, particularly if it is available in a heavier density. It ashes cleanly; there are few particles created with its use; and the latent and extractable $\mathrm{U}$ mass is about $10 \%$ of a typical TX304 cotton swipe. Additionally, the $\mathrm{U}$ content is natural, and the resulting ash does not perturb the $U$ isotopic signature when it is ignited in a furnace.

If the key to analysis is to isolate non-refractory $\mathrm{U}$ compounds from a sample, then the carbonate extraction method can be used but may have to be modified to dry and then destroy the carbonate solids thermally. The sample aliquot used for $U$ concentration could be spiked with ${ }^{233} U$ prior to evaporation, and isotope equilibration could also be incorporated for accurate IDMS analysis of U mass, although this would preclude ${ }^{233} \mathrm{U} /{ }^{238} \mathrm{U}$ analysis. Thermal destruction of carbonate would also permit high sensitivity measurement of minor $U$ isotopic ratios by MC-ICPMS. The accuracy of the isotopic analysis might still be dependent upon the extent and type of inorganic or organic contaminant present in a loaded swipe. A more reliable procedure for selective non-refractory $U$ compounds, combined with accurate determination of all $\mathrm{U}$ isotopes, would be to simply acidify the carbonate leach to $2-4 \mathrm{M}$. The $\mathrm{U}$ could then be separated from the concomitant sample contaminants on a UTEVA column. A combination of the leach and NWAL methods merges the advantages of each procedure in such a way that it will be selective for nonrefractory $\mathrm{U}$ while also meeting the measurement requirements for IAEA safeguards activities.

7. W. D. Bostick, "Treatability studies for anionic metal contaminants at a CERCLA Site" (conference paper, 242nd ACS National Meeting, Denver, CO, September 2011).

8. D. M. Hill and A. C. Alpin, "Role of colloids and fine particles in the transport of metals in rivers draining carbonate and silicate terrains," Limnology and Oceanography 46, no. 2 (2001): 331-344.

9. A. D. Karathanasis et al., "Biosolid colloid-mediated transport of copper, zinc, and lead in waste-amended soils," J. Environ. Qual. 34, no. 4 (2005): 1153-64. 


\section{REFERENCES}

Bostick, W. D. "Treatability studies for anionic metal contaminants at a CERCLA Site." Paper presented at the 242nd ACS National Meeting, Denver, CO, September 2011.

Clarens, F., J. de Pablo, I. Casa, J. Gimenez, M. Rovira, J. Merino, E. Cera, J. Bruno, J. Quinones, and A. Martinez-Esparza. "The oxidative dissolution of unirradiated $\mathrm{UO}_{2}$ by hydrogen peroxide as a function of pH.” J. Nucl Mater. 345 (2005): 225-231.

Croudace, I. W., P. Warwick, R. N. Taylor, and A. G. Cundy. "Investigation of an alleged nuclear incident at Greenham Common Airbase using TI-mass spectrometric measurements of uranium isotopes." Environ. Sci. Technol. 34 (2000): 4496-4503.

Currie, L. A. "Limits for qualitative detection and quantitative determination." Anal. Chem. 40, no. 3 (1968): 586-593.

Currie, L. A. "Detection: International update, and some emerging dilemmas involving calibration, the blank, and multiple detection decisions." Chemometrics and Intelligent Laboratory Systems 37 (1997): 151-181.

Hill, D. M. and A. C. Alpin. "Role of colloids and fine particles in the transport of metals in rivers draining carbonate and silicate terrains." Limnology and Oceanography 46, no. 2 (2001): 331-344.

Karathanasis, A. D., D. M. Johnson, and C. J. Matocha. "Biosolid colloid-mediated transport of copper, zinc, and lead in waste-amended soils." J Environ Qual. 34, no. 4 (2005): 1153-64.

Smith, S.C., S. M. Peper, M. Douglas, L. Z. Kate, and E. C. Finn. "Kinetic study of uranium residue dissolution in ammonium carbonate media." J. Radioanal Nucl. Chem. 282 (2009): 617-621.

White, D. A. and K. Edwards. "Degradation of ammonium carbonate based uranium leach solutions by sulphide minerals and possible methods of control." Hydrology (1982): 27-34. 